\title{
Repackaging Nitrite-Embedded Dark-Cutting Steak in Aerobic Polyvinyl Chloride Film Decreases Surface Redness $^{\text {a }}$
}

\author{
Morgan L. Denzer, Gretchen G. Mafi, Deborah L. VanOverbeke, and Ranjith Ramanathan* \\ Department of Animal and Food Sciences, Oklahoma State University, Stillwater, OK 74078, USA \\ *Corresponding author. Email: ranjith.ramanathan@okstate.edu (Ranjith Ramanathan) \\ aThis research was supported by the Oklahoma Center for the Advancement of Science and Technology, Oklahoma \\ Applied Research Support (AR18-025).
}

\begin{abstract}
The overall goal was to evaluate the effects of repackaging nitrite-embedded dark-cutting steaks in polyvinyl chloride (PVC) film on surface color. Dark-cutting beef strip loins $(n=8 ; \mathrm{pH}=6.39)$ and USDA Low Choice beef strip loins (USDA Choice, $n=6 ; \mathrm{pH}=5.56$ ) were selected at a commercial packing plant. Dark-cutting loins were bisected and randomly assigned to nonenhanced dark-cutting and enhanced dark-cutting with glucono delta-lactone and rosemary treatments. USDA Choice and nonenhanced dark-cutting steaks were vacuum packaged (VP) and served as controls, whereas enhanced dark-cutting steaks were packed in nitrite-embedded packaging (NP). Steaks from nonenhanced USDA Choice VP, nonenhanced dark-cutting VP, and enhanced dark-cutting NP loins were randomly assigned to 3, 6, or $9 \mathrm{~d}$ of dark storage. Following dark storage, steaks were repackaged in PVC and displayed for $6 \mathrm{~d}$ at $2^{\circ} \mathrm{C}$. Instrumental color, visual color, and aerobic plate count were evaluated for all steaks. Enhanced dark-cutting steaks in NP increased $(P<0.05) a^{*}$ values compared with USDA Choice and nonenhanced dark-cutting VP during $24 \mathrm{~h}$ of dark storage. Enhanced dark-cutting steaks packaged in NP had greater $a^{*}$ and $L^{*}$ values $(P<0.05)$ than nonenhanced dark-cutting VP steaks during dark storage. Upon repackaging the enhanced dark-cutting steaks from NP, nitric oxide myoglobin decreased $(P<0.05)$ during the first $12 \mathrm{~h}$ of display. Loss of nitric oxide myoglobin corresponds with a darker red appearance, increased surface discoloration, and decreased $a^{*}$ values. There were no differences $(P>0.05)$ in aerobic plate count between enhanced dark-cutting NP steaks and nonenhanced darkcutting VP steaks after repackaging. In conclusion, NP improved surface redness; however, repackaging enhanced darkcutting from NP steaks in PVC decreased color stability and redness of dark-cutting beef.
\end{abstract}

Key words: dark-cutting beef, meat color, nitrite-embedded packaging, antioxidant

\section{Introduction}

Consumers prefer to purchase meat products with a bright cherry-red color because of their interpretation of red appearance as an indication of freshness (Carpenter et al., 2001). Dark-cutting beef deviates from a preferred bright cherry-red color and appears as a dark red color owing to increased postmortem muscle pH (Lawrie, 1958; Scanga et al., 1998; Ramanathan et al., 2020a). Dark-cutting beef has worldwide occurrence, and carcasses are discounted at packing plants. In addition, dark-cutting beef is not sold at the retail level. Hence, it is critical to improve the appearance and value to maximize the economic benefits of producing animal proteins.

The occurrence of predominant oxymyoglobin, carboxymyoglobin, or nitric oxide myoglobin forms on the surface of steak imparts a consumer-preferred bright-red color. Hence, various post-harvest approaches, such as enhancement and modified atmospheric packaging, have been focused on counteracting the effects of greater-than-normal $\mathrm{pH}$ on surface color. 
Dark-cutting steaks in high-oxygen and carbon monoxide modified atmosphere packages had greater redness than steaks in polyvinyl chloride (PVC) (Wills et al., 2017; Mitacek et al., 2019; Zhang et al., 2018; Ramanathan et al., 2019). Greater lipid oxidation (Mitacek et al., 2018) and consumer safety concerns (Grebitus et al., 2013) limit the application of highoxygen and carbon monoxide modified atmosphere packaging, respectively, at the retail level.

Anaerobic nitrite-embedded packaging (NP) gives a bright-red color by the formation of nitric oxide myoglobin (Fox Jr. and Ackerman, 1968; Siegel, 2011). NP improved the redness of ground beef, steaks, and bison meat (Claus and Du, 2013; Yang et al., 2016; Robert et al., 2017). Previous research from our laboratory has shown that dark-cutting steaks in NP improved surface redness by $19 \%$ compared with PVC film owing to the formation of nitric oxide myoglobin (Ramanathan et al., 2018). Repackaging normal-pH steaks in NP or exposing nitric oxide myoglobin to atmospheric oxygen results in discoloration (Claus and $\mathrm{Du}, 2013$ ). Antioxidant enhancement and a greater-than-normal muscle $\mathrm{pH}$ have the potential to minimize discoloration of NP steaks when steaks are exposed to air. However, limited knowledge is currently available on the effects to surface color of repackaging high-pH/dark-cutting steaks in PVC.

A greater-than-normal postmortem muscle $\mathrm{pH}$ $(\mathrm{pH}>6.0$; normal $\mathrm{pH}=5.5-5.7)$ promotes the growth of spoilage organisms (Gill and Penney, 1986). Hence, enhancing dark-cutting steaks with a lower $\mathrm{pH}$ acid solution makes meat lighter and minimizes microbial growth (Apple et al., 2011). However, the use of strong acids can result in localized surface discoloration (Sawyer et al., 2009; Apple et al., 2011). Dolezal et al. (2013) utilized slow acidifying glucono delta-lactone to improve the color of dark-cutting beef. The combined effects of acidification and NP on the color of darkcutting beef have not been reported. Therefore, the objective of the current study was to evaluate the combination of glucono delta-lactone and NP on the surface color of dark-cutting beef longissimus lumborum steaks during storage and to evaluate the color stability of repackaged steaks in PVC during 6-d retail display.

\section{Materials and Methods}

\section{Raw materials and processing}

Eight dark-cutting strip loins $(\mathrm{pH}=6.21-6.77$; longissimus lumborum; Institutional Meat Purchasing
Specifications \#184) and 6 USDA Low Choice strip loins (USDA Choice; $\mathrm{pH}=5.53-5.59$; longissimus lumborum; Institutional Meat Purchasing Specifications \#184) less than $7 \mathrm{~d}$ postmortem were collected from a local purveyor (Creekstone Farms, Arkansas City, KS). Vacuum-packaged (VP) strip loins were transported on ice to the Robert M. Kerr Food and Agricultural Products Center at Oklahoma State University campus in Stillwater. Upon arrival, USDA Choice and dark-cutting loins were bisected, vacuum packaged (Walton's Vacuum Pouch; $12 \times 22$ pouches; 3 mil thickness; $1.3-1.6$ oxygen transmission rate $\mathrm{cm}^{3} / 100 \mathrm{in}^{2}$; Walton's Inc., Wichita, KS) using a Multivac C5000 vacuum packager (Multivac, Kansas City, MO; vacuum level $=20$ inches $\mathrm{Hg}$ ), and stored in the dark at $2^{\circ} \mathrm{C}$ until use. At $7 \mathrm{~d}$ postmortem, each half of dark-cutting strip loins was randomly assigned either to enhancement with glucono delta-lactone and rosemary or to nonenhanced (Figure 1). Loins were injected with a handheld multineedle injection system (Leeson motor; Grafton, WI) at $10 \%$ of the raw meat weight basis with a combination of rosemary (Herbalox oleoresin rosemary; Kalsec, Kalamazoo, MI) and glucono delta-lactone solution (glucono delta-lactone; PMP Fermentation Products, Inc., Peoria, IL) to achieve a final concentration of $0.1 \%$ and $0.5 \%$, respectively. Loins were rested for $2 \mathrm{~h}$ after enhancement, and each loin was rotated manually every $10 \mathrm{~min}$ to allow for more dispersion of enhancement solution. The average injection level was $9.9 \%$ (standard error $=0.1 \%$ ). Enhanced dark-cutting loins, nonenhanced dark-cutting loins, and USDA Choice loins were sliced into 1.91-cm-thick steaks from the anterior end using a meat slicer (Bizerba USA Inc., Piscataway, NJ).

\section{pH}

The initial $\mathrm{pH}$ of USDA Choice and nonenhanced dark-cutting strip loins was measured at 3 random locations using a Hanna Instruments $\mathrm{pH}$ probe (Handheld HI 99163; probe FC232; Hanna Instruments, Woonsocket, $\mathrm{RI})$. The $\mathrm{pH}$ of enhanced dark-cutting strip loins was measured at 3 locations after a 2-h rest period. On day 6 of retail display, steaks were removed, and the $\mathrm{pH}$ was measured in triplicate for each steak.

\section{Packaging and simulated retail display}

Steaks from nonenhanced dark-cutting, enhanced dark-cutting, and USDA Choice loins were randomly selected for 3, 6, or $9 \mathrm{~d}$ of dark storage. Enhanced darkcutting steaks were packaged in nitrite-embedded film (FreshCase; Curlon Grade A5106 Protective Packaging 
Film; approximately $115 \mathrm{mg} / \mathrm{m}^{2}$ nitrite, $6 \times 12$ pouches; 7 mil thickness; $<0.15$ oxygen transmission rate $\mathrm{cm}^{3} /$ $100 \mathrm{in}^{2} / 24 \mathrm{~h}$ at $73^{\circ} \mathrm{F}, 1$ atmosphere; $<0.5$ water vapor transmission rate $\mathrm{g} / 100 \mathrm{in}^{2} / 24 \mathrm{~h}$ at $100^{\circ} \mathrm{F}, 90 \%$ relative humidity, 1 atmosphere; Neenah, WI). Nonenhanced dark-cutting steaks and USDA Choice steaks were vacuum packaged (FlairPak 500 Vacuum Pouch; $10 \times 14$ pouches; 4.7 mil thickness; $1.3-1.6$ oxygen transmission rate $\mathrm{cm}^{3} / 100 \mathrm{in}^{2}$; Appleton, WI) using a Multivac C5000 vacuum packager. Steaks were stored in the dark for 3, 6, or $9 \mathrm{~d}$ at $2^{\circ} \mathrm{C} \pm 1^{\circ} \mathrm{C}$. After 3,6 , or $9 \mathrm{~d}$ in dark storage, steaks were removed from the anaerobic packaging systems and placed on Styrofoam trays with absorbent pads and overwrapped with PVC $\left(15,500-16,275 \mathrm{~cm}^{3} \mathrm{O}_{2} / \mathrm{m}^{2} / 24 \mathrm{~h}\right.$ at $23^{\circ} \mathrm{C}$; E-Z Wrap Crystal Clear Polyvinyl Chloride Wrapping Film, Koch Supplies, Kansas City, MO) using a film wrap machine (Winholt WHSS-1, 115V;
Woodbury, NY). Packaged steaks were placed in a white coffin-style display case and stored under continuous fluorescent lighting (772 to 1,056 lux, Philips fluorescent lamps; 12 watts, 48 inches length, color temperature $=$ $3,500^{\circ} \mathrm{K}$; Phillips, China) at $2^{\circ} \mathrm{C} \pm 1^{\circ} \mathrm{C}$ for $6 \mathrm{~d}$.

\section{Instrumental and visual color analysis}

During dark storage, the instrumental color of steaks was measured every $24 \mathrm{~h}$ using a HunterLab 4500L MiniScan EZ Spectrophotometer (2.5-cm aperture, illuminant $\mathrm{A}$, and $10^{\circ}$ standard observer angle; HunterLab Associates, Reston, VA). The HunterLab MiniScan spectrophotometer was standardized using white and black tiles. Owing to the thickness of the $\mathrm{NP}$, the film was not used in the standardization process. The surface of each steak was read twice to record

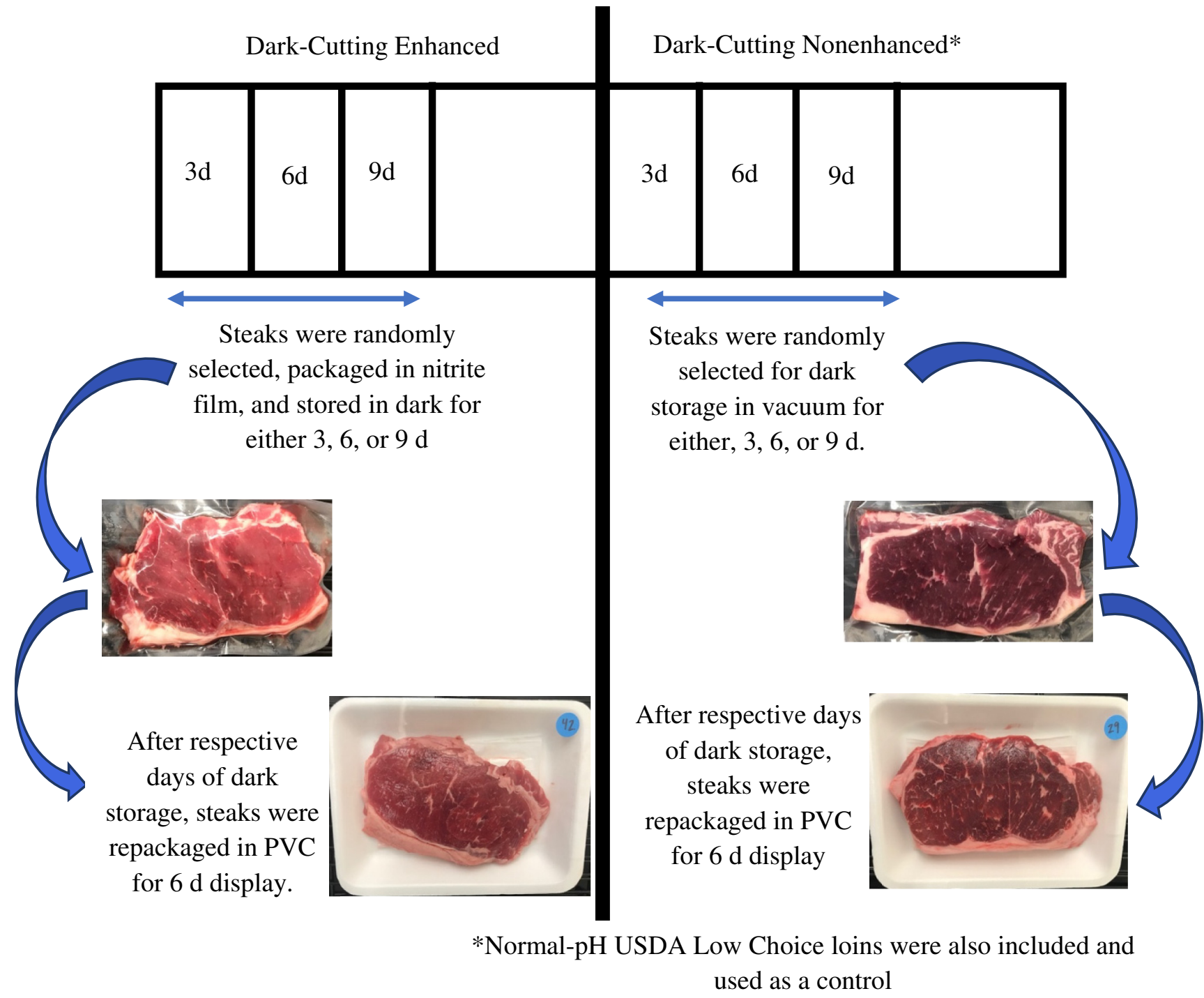

Figure 1. Schematic representation of enhancement and packaging of dark-cutting loins during dark storage and repackaging of steaks for retail display (USDA Choice: $n=6$; DCN/DCE: $n=8$ ). DCE = dark cutting enhanced; DCN = dark cutting nonenhanced; PVC = polyvinyl chloride. 
the Commission International de l'éclairage (CIE) $L^{*}$, $a^{*}$, and $b^{*}$ values. The reflectance from 400 to $700 \mathrm{~nm}$ was also recorded to evaluate nitric oxide formation during dark storage. The first $3 \mathrm{~d}$ of dark storage were reported to represent the shift to nitric oxide myoglobin in the NP. Upon repackaging, steaks bloomed for $30 \mathrm{~min}$ prior to color evaluation and were read in duplicate every $12 \mathrm{~h}$ for $6 \mathrm{~d}$. The CIE $L^{*}, a^{*}$, and $b^{*}$ values and spectral readings from 400 to $700 \mathrm{~nm}$ were utilized to determine surface color. Chroma $\left.\left[\sqrt{\left(a^{* 2}+b^{* 2}\right.}\right)\right]$ was determined using CIE $a^{*}$ and $b^{*}$ values (AMSA, 2012). The nitric oxide myoglobin formation was determined on enhanced dark-cutting NP steaks and calculated as the ratio of reflectance at 650 and $570 \mathrm{~nm}$, with a greater number indicating a greater amount of nitric oxide myoglobin and hemoglobin (AMSA, 2012). CIE $a^{*}$ and $b^{*}$ were used to determine the hue angle $\left(\tan ^{-1}\left(\frac{b^{*}}{a^{*}}\right)\right)$, which indicates discoloration (AMSA, 2012).

Visual color was evaluated by a trained panel $(n=6)$ for all repackaged steaks during 6-d display period. All panelists passed the Farnsworth Munsell

A 60

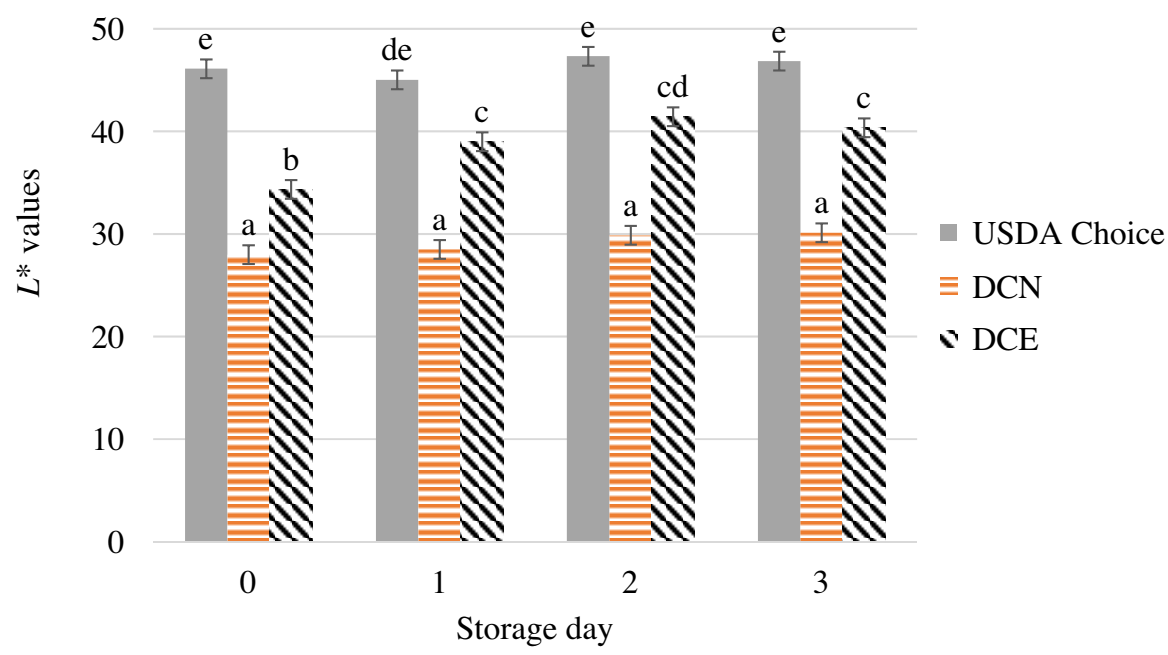

B 35

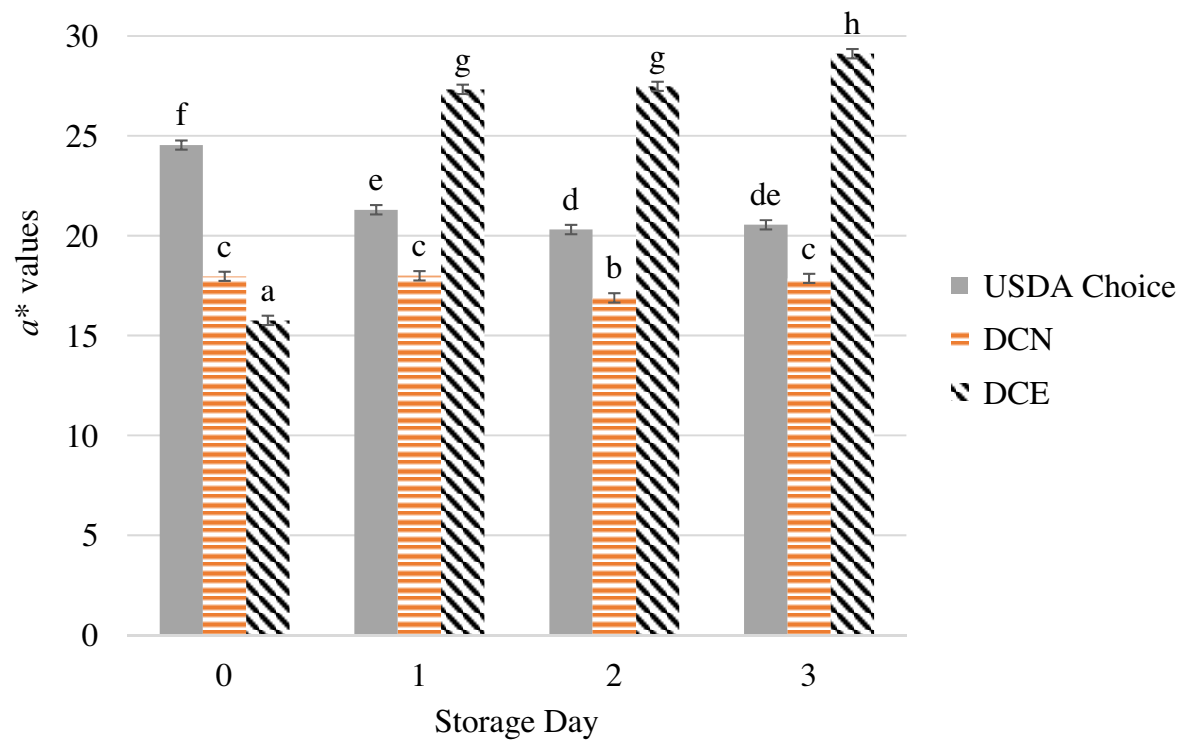

Figure 2. Effects of dark storage day and enhancement on dark storage $L^{*}$ values (panel A) and $a^{*}$ values (panel B). Least-squares means with different letters $(\mathrm{a}-\mathrm{h})$ within an attribute are significantly different $(P<0.05)$. Standard error of the mean indicated by error bars $(\operatorname{SEM}(\mathrm{A})=0.91 ; \operatorname{SEM}(\mathrm{B})=0.24)$. Treatments include normal-pH USDA Low Choice strip loin $(n=6)$, nonenhanced dark-cutting (DCN) steaks in vacuum packaging $(n=8)$, and dark-cutting steaks enhanced (DCE) with $0.5 \%$ glucono delta-lactone and $0.1 \%$ rosemary solution and in nitrite-embedded packaging $(n=8)$. 
85-hue test (Kinnear and Sahraie, 2002). Panelists determined muscle color using a 7-point scale $(1=$ extremely bright cherry-red, $7=$ dark red) and surface discoloration using a 7 -point scale $(1=$ no discoloration $[0 \%], 7=$ extensive discoloration [ $81 \%-100 \%]$ ) every $12 \mathrm{~h}$ for $6 \mathrm{~d}$.

\section{Aerobic plate count}

The total plate count of repackaged USDA Choice, enhanced dark-cutting NP, and nonenhanced darkcutting VP steaks in PVC was determined on day 6 of display. The surface of steaks was swabbed using a sterile $2.54 \times 2.54 \mathrm{~cm}^{2}$ grid and an environmental swab (Puritan Environmental Sampling Kit HP007-BPW Puritan Medical Products Co LLC, Guildford, ME). One milliliter from the swab container was serially diluted into
$9 \mathrm{~mL}$ of $0.1 \%$ sterile peptone water (Bacto Peptone Ref 211677 Becton; Dickinson and Company, Sparks, MD). On 3M Petrifilm Rapid Aerobic Count plates (3M Health Care, St. Paul, MN), 1 milliliter from each dilution was aseptically plated in duplicate. Plates were incubated at $37^{\circ} \mathrm{C}$ for $48 \mathrm{~h}$ in a VWR Forced Air General Incubator (5.4 $\mathrm{ft}^{3}$; VWR, Radnor, PA). After $48 \mathrm{~h}$ of incubation, plates were removed and counted to determine the total plate count per centimeter square area using an Interscience Scan 100 pressure-sensitive pad (Interscience, Woburn, MA).

\section{Statistical analysis}

The experimental design was a split-split plot. In the whole plot, each dark-cutting loin section was randomly
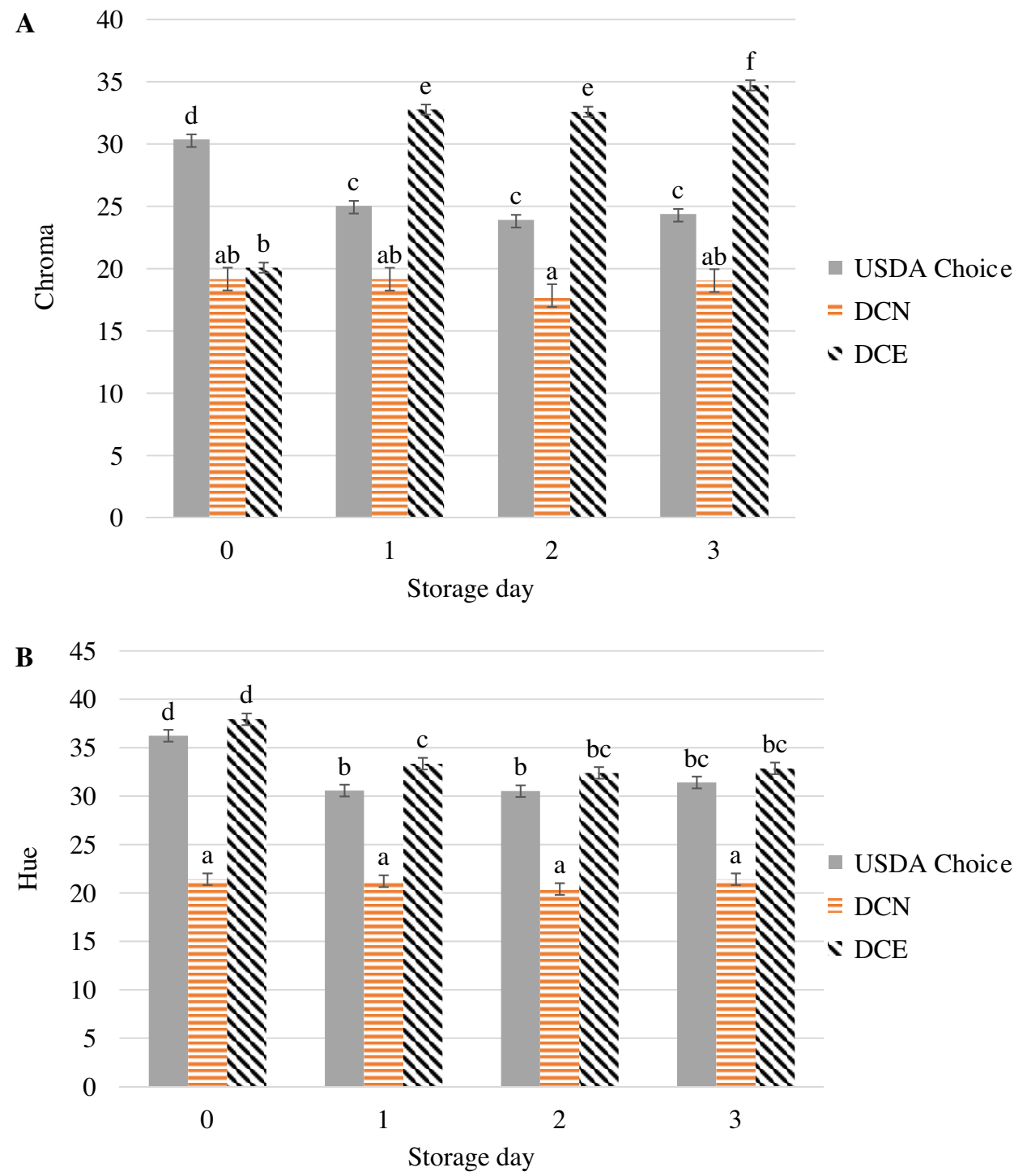

Figure 3. Effects of dark storage day and enhancement on dark storage chroma (panel A) and hue (panel B). Least-squares means with different letters $(\mathrm{a}-\mathrm{f})$ within an attribute are significantly different $(P<0.05)$. Standard error of the mean indicated by error bars $(\mathrm{SEM}(\mathrm{A})=0.41$; $\mathrm{SEM}(\mathrm{B})=0.60)$. Treatments include normal-pH USDA Low Choice steaks $(n=6)$, nonenhanced dark-cutting (DCN) steaks in vacuum packaging $(n=8)$, and dark-cutting steaks enhanced (DCE) with $0.5 \%$ glucono delta-lactone and $0.1 \%$ rosemary solution and in nitrite-embedded packaging $(n=8)$. 
assigned to enhanced dark-cutting $(n=8)$ and nonenhanced dark-cutting $(n=8)$. In the sub-plot (splitfactor), nonenhanced dark-cutting VP and enhanced dark-cutting NP sections were cut into steaks and assigned to 3,6 , or $9 \mathrm{~d}$ in dark storage. In the sub-sub plot, steaks assigned to 3,6 , or $9 \mathrm{~d}$ of dark storage are repackaged in PVC for simulated retail display. The fixed effects include enhancement treatment, storage time in dark storage, display time in PVC, and their interactions. The fixed effects for nitric oxide myoglobin content were dark storage time and display time because nitric oxide myoglobin was only evaluated for enhanced dark-cutting NP steaks. The loin was a random effect, and storage time was a repeated measure. The covariance-variance structure for the repeated measures was determined by evaluating the Akaike Information Criterion output, and the compound symmetry structure was used based on the Akaike Information Criterion value. Least-squares means were determined using the MIXED procedure of SAS (SAS version 9.4; SAS Institute Inc., Cary, NC) and considered significant at $P<0.05$. Using the PDIFF options, least-squares means were separated and considered significant at $P<0.05$. Steaks in NP were stored for $9 \mathrm{~d}$, and the maximum color changes occurred during the first $3 \mathrm{~d}$ of storage. Hence, least-squares means were reported only for the first $3 \mathrm{~d}$ of dark storage to demonstrate the shift to nitric oxide myoglobin in NP.

\section{Results}

\section{pH}

Dark-cutting loins had greater $\mathrm{pH}(\mathrm{pH}=6.39 \pm$ 0.04; mean \pm standard error, $P<0.05$ ) than USDA Choice loins $(\mathrm{pH}=5.56 \pm 0.04)$. After 6-d display, the $\mathrm{pH}$ of enhanced dark-cutting steaks was lower $(\mathrm{pH}=5.88 \pm 0.09, P<0.05)$ than nonenhanced darkcutting steaks $(\mathrm{pH}=6.42 \pm 0.09)$.

\section{Effects of dark storage and nitrite packaging on color}

Lightness ( $\boldsymbol{L}^{*}$ values). There was a significant dark storage day $\times$ enhancement interaction for $L^{*}$ values (Figure 2A). The USDA Choice steaks were lighter $\left(P<0.05\right.$, greater $\left.L^{*}\right)$ compared with nonenhanced dark cutting VP and enhanced dark-cutting NP steaks (Figure 2A) throughout storage time. The $L^{*}$ values of nonenhanced dark-cutting VP steaks did not change and were lower than USDA Choice and enhanced dark-cutting NP steaks throughout the first $3 \mathrm{~d}$ of storage. After $72 \mathrm{~h}$, the $L^{*}$ values of nonenhanced darkcutting VP steaks remained lower $(P<0.05)$ than the enhanced dark-cutting NP steaks.

Table 1. Effects of dark storage day ${ }^{1}$ on the nitric oxide myoglobin formation ${ }^{2}$ in the enhanced dark-cutting steaks packaged in nitrite-embedded packaging $(n=8)$

\begin{tabular}{ll}
\hline \hline Dark storage day & Nitric oxide myoglobin formation \\
\hline 0 & $2.37^{\mathrm{a}}$ \\
1 & $5.60^{\mathrm{b}}$ \\
2 & $5.27^{\mathrm{b}}$ \\
3 & $6.01^{\mathrm{c}}$ \\
SEM $=0.08$ & \\
\hline
\end{tabular}

\footnotetext{
${ }^{1}$ Specific day during dark storage the parameter was measured.

${ }^{2}$ Nitric oxide myoglobin formation was calculated as the ratio of R650 $\div$ $\mathrm{R} 570 \mathrm{~nm}$. A greater number indicates more nitric oxide formation.

${ }^{\mathrm{a}-\mathrm{c}}$ Least-squares means with different letters are significantly different $(P<0.05)$.

$\mathrm{SEM}=$ standard error of mean.
}

Table 2. Least-squares means for $L^{*}$ (enhancement ${ }^{1} \times$ hour of retail display) of repackaged steaks displayed for $144 \mathrm{~h}$

\begin{tabular}{|c|c|c|}
\hline Retail display hour & Enhancement & $L^{*}$ values \\
\hline \multirow[t]{3}{*}{0} & USDA Choice & $45.70^{\mathrm{i}}$ \\
\hline & $\mathrm{DCN}$ & $33.54^{\mathrm{abc}}$ \\
\hline & DCE & $39.34^{\text {fgh }}$ \\
\hline \multirow[t]{3}{*}{12} & USDA Choice & $46.56^{\mathrm{i}}$ \\
\hline & $\mathrm{DCN}$ & $33.90^{\mathrm{abcd}}$ \\
\hline & DCE & $38.52^{\mathrm{fg}}$ \\
\hline \multirow[t]{3}{*}{24} & USDA Choice & $46.35^{\mathrm{i}}$ \\
\hline & $\mathrm{DCN}$ & $33.86^{\mathrm{abc}}$ \\
\hline & DCE & $38.18^{\text {def }}$ \\
\hline \multirow[t]{3}{*}{72} & USDA Choice & $45.58^{\mathrm{i}}$ \\
\hline & $\mathrm{DCN}$ & $34.06^{\text {abcde }}$ \\
\hline & DCE & $37.81^{\text {cdef }}$ \\
\hline \multirow[t]{3}{*}{84} & USDA Choice & $45.06^{\mathrm{i}}$ \\
\hline & $\mathrm{DCN}$ & $33.22^{\mathrm{ab}}$ \\
\hline & DCE & $38.30^{\mathrm{ef}}$ \\
\hline \multirow[t]{3}{*}{132} & USDA Choice & $43.31^{\mathrm{hi}}$ \\
\hline & $\mathrm{DCN}$ & $31.59^{\mathrm{a}}$ \\
\hline & DCE & $37.26^{\text {bcdef }}$ \\
\hline \multirow[t]{3}{*}{144} & USDA Choice & $42.63^{\mathrm{ghi}}$ \\
\hline & $\mathrm{DCN}$ & $32.20^{\mathrm{a}}$ \\
\hline & DCE & $37.36^{\text {bcdef }}$ \\
\hline
\end{tabular}

${ }^{1}$ Treatments include normal-pH USDA Low Choice strip loin, nonenhanced dark-cutting steals in vacuum packaging (DCN), and darkcutting strip loin enhanced with $0.5 \%$ glucono delta-lactone and $0.1 \%$ rosemary solution and in nitrite-embedded packaging (DCE).

USDA Choice, $n=6$; nonenhanced and enhanced dark-cutting, $n=8$; SEM $=$ standard error of mean.

${ }^{\mathrm{a}-\mathrm{i}}$ Least-squares means with different letters are significantly different $(P<0.05)$. 
Redness ( $a^{*}$, hue, and chroma). There was a significant dark storage day $\times$ enhancement interaction for $a^{*}$ values, hue, and chroma (Figure 2B and Figure 3A-3B). Within $1 \mathrm{~d}$, enhanced dark-cutting-NP steaks increased in $a^{*}$ values and were redder $(P<0.05)$ than USDA Choice VP steaks (Figure 2B). The redness of USDA Choice VP steaks significantly decreased from day 0 to day 1 of dark storage. The USDA Choice VP steaks had a decrease in chroma and $a^{*}$ values from day 0 to day 1 due to the formation of deoxymyoglobin. Nonenhanced dark-cutting VP steaks had minimal changes in redness and had no change $(P<0.05)$ in chroma values during the first 3 $\mathrm{d}$ of dark storage (Figure 3A). A greater hue angle indicates a change from red to yellow and increased discoloration. Nonenhanced dark-cutting VP steaks did not demonstrate a change $(P>0.05)$ in hue angle throughout the $3 \mathrm{~d}$ of dark storage (Figure 3B). Hue angle of USDA Choice VP steaks decreased $(P<0.05)$ from day 0 to day 1 . The enhanced dark-cutting NP steaks paralleled in hue changes with the USDA Choice steaks. The highest hue angle was on day 0 , and significantly decreased by day 1 of dark storage. The decrease in hue angle values (indicating less discoloration) occurred after the first day of dark storage for the enhanced darkcutting NP steaks.

Nitric oxide myoglobin formation. There was a dark storage day effect $(P<0.05)$ on the nitric oxide myoglobin formed for enhanced dark-cutting NP steaks (Table 1). Nitric oxide myoglobin content increased $(P<0.05)$ within $24 \mathrm{~h}$ of dark storage. Day 3 enhanced dark-cutting NP had a greater $(P<0.05)$ ratio of $\mathrm{R} 650 \div$ $\mathrm{R} 570 \mathrm{~nm}$ than day 2 enhanced dark-cutting NP, indicating an increase in nitric oxide myoglobin content.

\section{Effects of repackaging anaerobically packaged steaks in polyvinyl chloride film on retail display color}

Lightness ( $L^{*}$ values). A significant interaction of enhancement $\times$ hour of retail display in PVC resulted for $L^{*}$ values (Table 2 ). At time $0 \mathrm{~h}$ of retail display, repackaged enhanced dark-cutting steaks were lighter $(P<0.05)$ than repackaged nonenhanced dark-cutting

Table 3. Least-squares means for $a^{*}$ and chroma (dark storage time $e^{1} \times$ enhancement $^{2} \times$ hour of retail display) of repackaged steaks displayed for $144 \mathrm{~h}$

\begin{tabular}{|c|c|c|c|c|c|c|c|c|c|}
\hline \multirow[b]{2}{*}{ Parameter } & \multirow[b]{2}{*}{ Dark storage time } & \multirow[b]{2}{*}{ Enhancement } & \multicolumn{7}{|c|}{ Retail display hour } \\
\hline & & & 0 & 12 & 24 & 72 & 84 & 132 & 144 \\
\hline \multirow[t]{6}{*}{$a^{*}$ values } & $3 \mathrm{~d}$ & USDA Choice & $28.04^{\mathrm{abwx}}$ & $31.69^{\mathrm{bw}}$ & $31.12^{\mathrm{abz}}$ & $29.65^{\text {aby }}$ & $29.45^{\text {aby }}$ & $28.10^{\text {aby }}$ & $26.70^{\text {ay }}$ \\
\hline & & $\mathrm{DCN}$ & $22.69^{\mathrm{av}}$ & $23.67^{\mathrm{av}}$ & $24.62^{\mathrm{axy}}$ & $24.32^{\mathrm{awx}}$ & $24.38^{\mathrm{avwx}}$ & $22.32^{\mathrm{awx}}$ & $22.11^{\mathrm{awx}}$ \\
\hline & & DCE & $27.84^{\text {bwx }}$ & $21.12^{\mathrm{av}}$ & $19.97^{\mathrm{avw}}$ & $20.46^{\mathrm{avw}}$ & $20.69^{\mathrm{av}}$ & $17.79^{\mathrm{avw}}$ & $18.65^{\mathrm{avw}}$ \\
\hline & $6 \mathrm{~d}$ & USDA Choice & $27.34^{\mathrm{abwx}}$ & $30.49^{\mathrm{bw}}$ & $30.29^{\mathrm{bz}}$ & $29.24^{\text {aby }}$ & $28.83^{\mathrm{abxy}}$ & $26.32^{\mathrm{abxy}}$ & $24.97^{\text {axy }}$ \\
\hline & & DCN & $23.89^{\text {bvw }}$ & $23.57^{\text {bv }}$ & $23.93^{\mathrm{bwx}}$ & $24.01^{\text {bvwx }}$ & $23.59^{\mathrm{bvw}}$ & $18.57^{\mathrm{avw}}$ & $18.42^{\mathrm{avw}}$ \\
\hline & & DCE & $28.77^{\mathrm{bx}}$ & $20.02^{\mathrm{av}}$ & $18.40^{\mathrm{av}}$ & $19.52^{\mathrm{av}}$ & $20.20^{\mathrm{av}}$ & $20.27^{\mathrm{avw}}$ & $20.10^{\mathrm{avw}}$ \\
\hline \multirow[t]{3}{*}{$\mathrm{SEM}=1.14$} & $9 \mathrm{~d}$ & USDA Choice & $25.46^{\mathrm{bvwx}}$ & $29.45^{\text {bw }}$ & $29.00^{\text {byz }}$ & $27.65^{\mathrm{bxy}}$ & $27.61^{\text {bwxy }}$ & $19.60^{\mathrm{avw}}$ & $17.75^{\mathrm{avw}}$ \\
\hline & & $\mathrm{DC}$ & $23.66^{\mathrm{bvw}}$ & $23.82^{\mathrm{bv}}$ & $24.12^{\mathrm{bwx}}$ & $22.13^{\mathrm{bvw}}$ & $20.61^{\mathrm{abv}}$ & $16.75^{\text {av }}$ & $16.40^{\mathrm{av}}$ \\
\hline & & DCE & $27.48^{\mathrm{cwx}}$ & $20.26^{\mathrm{abv}}$ & $21.06^{\mathrm{abvwx}}$ & $21.51^{\mathrm{bvw}}$ & $19.90^{\mathrm{abv}}$ & $17.08^{\mathrm{abv}}$ & $16.82^{\mathrm{av}}$ \\
\hline \multirow[t]{6}{*}{ Chroma } & $3 \mathrm{~d}$ & USDA Choice & $35.25^{\mathrm{abz}}$ & $39.92^{\mathrm{bx}}$ & $39.18^{\text {by }}$ & $37.16^{\text {aby }}$ & $37.13^{\text {aby }}$ & $35.31^{\text {aby }}$ & $33.63^{\mathrm{az}}$ \\
\hline & & $\mathrm{DCN}$ & $26.93^{\text {aw }}$ & $28.83^{\text {aw }}$ & $30.23^{\mathrm{ax}}$ & $29.89^{\mathrm{awx}}$ & $30.04^{\text {axy }}$ & $27.41^{\mathrm{ax}}$ & $27.16^{\text {axy }}$ \\
\hline & & DCE & $33.84^{\mathrm{bz}}$ & $26.78^{\mathrm{aw}}$ & $25.81^{\text {awx }}$ & $26.34^{\mathrm{aw}}$ & $26.64^{\mathrm{awx}}$ & $23.27^{\mathrm{awx}}$ & $24.21^{\text {awx }}$ \\
\hline & $6 \mathrm{~d}$ & USDA Choice & $34.71^{\mathrm{abcz}}$ & $38.60^{\mathrm{cx}}$ & $38.04^{\text {bcy }}$ & $36.76^{\text {bcy }}$ & $36.27^{\mathrm{abcy}}$ & $33.21^{\text {aby }}$ & $31.68^{\mathrm{ayz}}$ \\
\hline & & $\mathrm{DCN}$ & $28.54^{\text {bwxy }}$ & $28.49^{\mathrm{bw}}$ & $29.07^{\mathrm{bwx}}$ & $29.22^{\mathrm{bw}}$ & $28.65^{\mathrm{bwx}}$ & $22.53^{\mathrm{awx}}$ & $22.27^{\text {awx }}$ \\
\hline & & DCE & $35.22^{\mathrm{bz}}$ & $25.99^{\mathrm{aw}}$ & $24.50^{\mathrm{aw}}$ & $25.66^{\mathrm{aw}}$ & $26.29^{\mathrm{awx}}$ & $26.01^{\mathrm{ax}}$ & $25.62^{\mathrm{ax}}$ \\
\hline \multirow[t]{3}{*}{$\mathrm{SEM}=1.25$} & $9 \mathrm{~d}$ & USDA Choice & $32.57^{\text {bwyz }}$ & $37.13^{\mathrm{bx}}$ & $36.86^{\text {by }}$ & $34.89^{\mathrm{bxy}}$ & $34.58^{\text {by }}$ & $26.15^{\mathrm{ax}}$ & $23.97^{\text {awx }}$ \\
\hline & & DCN & $28.23^{\mathrm{cwx}}$ & $28.72^{\mathrm{cw}}$ & $29.18^{\mathrm{cwx}}$ & $26.53^{\mathrm{cw}}$ & $24.47^{\mathrm{bcw}}$ & $19.89^{\mathrm{abw}}$ & $19.36^{\text {aw }}$ \\
\hline & & DCE & $33.49^{\mathrm{byz}}$ & $25.65^{\mathrm{aw}}$ & $26.55^{\mathrm{awx}}$ & $27.28^{\text {aw }}$ & $25.55^{\mathrm{awx}}$ & $22.58^{\mathrm{awx}}$ & $22.66^{\text {awx }}$ \\
\hline
\end{tabular}

${ }^{1}$ Total time the steaks spent in dark storage prior to retail display.

${ }^{2}$ Treatments include normal-pH USDA Low Choice strip loin, nonenhanced dark-cutting steaks in vacuum packaging (DCN), and dark-cutting steaks enhanced with $0.5 \%$ glucono delta-lactone and $0.1 \%$ rosemary solution and in nitrite-embedded packaging (DCE).

USDA Choice, $n=6$; DCN/DCE, $n=8$.

${ }^{\mathrm{a}-\mathrm{c}}$ Least-squares means within a row with different letters are significantly different $(P<0.05)$.

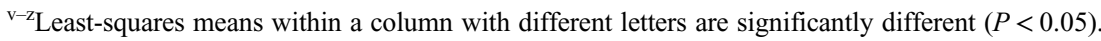

$\mathrm{SEM}=$ standard error of mean . 
steaks. The USDA Choice steaks at $0 \mathrm{~h}$ had greater $L^{*}$ values than $144 \mathrm{~h}$ USDA Choice steaks.

Redness ( $a^{*}$ and chroma). There was a significant dark storage time $\times$ enhancement $\times$ hour of retail display in PVC effect on $a^{*}$ values and chroma (Table 3). At time $0 \mathrm{~h}$ of retail display, enhanced dark-cutting steaks in NP had greater $a^{*}$ and chroma values $(P<0.05)$ than nonenhanced dark-cutting steaks during all dark storage time. At $0 \mathrm{~h}$, enhanced dark-cutting steaks in NP had similar $a^{*}$ and chroma values $(P>0.05)$ to USDA Choice VP steaks. Nonenhanced dark-cutting steaks that were in vacuum and stored for $3 \mathrm{~d}$ in dark storage did not demonstrate a change $(P>0.05)$ in $a^{*}$ and chroma values during retail display; however, nonenhanced dark-cutting steaks that were in vacuum and stored for $6 \mathrm{~d}$ or $9 \mathrm{~d}$ in dark storage decreased significantly in $a^{*}$ and chroma values by hour 132 compared with hour 0 of retail display. PVC repackaged enhanced dark-cutting NP steaks had a significant decrease in $a^{*}$ and chroma values from hour 0 to hour 12 . After $12 \mathrm{~h}$, the repackaged enhanced dark-cutting NP steaks had lower $(P<0.05) a^{*}$ values than USDA Choice for all dark storage times; however, PVC repackaged steaks from enhanced dark-cutting NP and nonenhanced darkcutting VP were not different at $12 \mathrm{~h}$. By the end of retail display, $\mathrm{PVC}$ repackaged enhanced dark-cutting NP and nonenhanced dark-cutting VP steaks demonstrated no differences $(P>0.05)$ in $a^{*}$ values for all dark storage times. However, PVC repackaged USDA Choice steaks were redder $(P<0.05)$ than repackaged enhanced dark-cutting NP and nonenhanced dark-cutting VP steaks stored $3 \mathrm{~d}$ and $6 \mathrm{~d}$ in dark storage at the end of display.

The ratio of $\mathrm{R} 650 \div \mathrm{R} 570 \mathrm{~nm}$ was significantly impacted by the hour of retail display for PVC repackaged enhanced dark-cutting NP steaks (Table 4). The only loss $(14.4 \%, P<0.05)$ in nitric oxide myoglobin between 12-h measurement periods occurred in the first $12 \mathrm{~h}$ of display. The next loss of nitric oxide myoglobin from the display did not occur until $108 \mathrm{~h}$, after which no additional loss occurred. The decrease in nitric oxide myoglobin ratio in PVC repackaged enhanced dark-cutting NP steaks aligned with $a^{*}$ and chroma results.

Visual color. For muscle color and surface discoloration, there was a significant dark storage time $\times$ enhancement $\times$ hour of retail display in PVC interaction (Table 5). Dark storage time had minimal effects on the muscle color and surface discoloration at hour 0 of display within each enhancement. USDA Choice steaks stored for $3 \mathrm{~d}$ and $6 \mathrm{~d}$ in dark increased in muscle color
Table 4. Effects of hour of retail display on nitric oxide formation $^{1}$ of the repackaged enhanced ${ }^{2}$ darkcutting steaks $(n=8)$

\begin{tabular}{ll}
\hline \hline Retail display hour & Nitric oxide myoglobin formation \\
\hline 0 & $5.49^{\mathrm{d}}$ \\
12 & $4.70^{\mathrm{c}}$ \\
24 & $4.65^{\mathrm{c}}$ \\
36 & $4.58^{\mathrm{bc}}$ \\
48 & $4.54^{\mathrm{bc}}$ \\
60 & $4.51^{\mathrm{bc}}$ \\
72 & $4.44^{\mathrm{abc}}$ \\
84 & $4.40^{\mathrm{abc}}$ \\
96 & $4.32^{\mathrm{abc}}$ \\
108 & $4.00^{\mathrm{ab}}$ \\
120 & $4.07^{\mathrm{abc}}$ \\
132 & $3.85^{\mathrm{a}}$ \\
144 & $3.86^{\mathrm{a}}$ \\
SEM $=0.16$ & \\
\hline
\end{tabular}

${ }^{1}$ Nitric oxide myoglobin formation was calculated as the ratio of reflectance $(\mathrm{R}) 650 \div \mathrm{R} 570 \mathrm{~nm}$. A greater number indicates more nitric oxide formation.

${ }^{2}$ Dark-cutting steaks were enhanced with $0.5 \%$ glucono delta-lactone and $0.1 \%$ rosemary solution and packaged in nitrite embedded film.

${ }^{\mathrm{a}-\mathrm{d}}$ Least-squares means with different letters are significantly different $(P$ $<0.05)$.

$\mathrm{SEM}=$ standard error of mean

score, with the muscle color becoming darker red as display time increased. However, at $0 \mathrm{~h}$ of retail display, PVC repackaged USDA Choice steaks were significantly brighter red in appearance compared with enhanced dark-cutting and nonenhanced dark-cutting steaks during all dark storage times. The panelists noted no discoloration on PVC repackaged USDA Choice, nonenhanced dark-cutting VP, and enhanced darkcutting NP steaks $(P>0.05)$ at hour 0 of display. Repackaged nonenhanced dark-cutting VP had a darker appearance at hour 0 and 12 than USDA Choice and enhanced dark-cutting NP steaks. Additionally, repackaged nonenhanced dark-cutting VP steaks did not significantly change in muscle color as display hour increased for all dark storage times; therefore, the dark storage time had no effect on the muscle color of repackaged nonenhanced dark-cutting VP steaks. Enhanced dark-cutting NP steaks had brighter $(P<0.05)$ red color than repackaged nonenhanced dark-cutting VP steaks at hour 0 but significantly decreased in redness within $12 \mathrm{~h}$ of display for steaks stored $3 \mathrm{~d}$ and $9 \mathrm{~d}$ in dark storage. This parallels with the significant decrease in nitric oxide myoglobin, $a^{*}$ values, and chroma in the first $12 \mathrm{~h}$ of display. The muscle color of repackaged enhanced dark-cutting NP steaks was equivalent $(P>0.05)$ to repackaged 
Table 5. Least-squares means for muscle color ${ }^{1}$ and surface discoloration ${ }^{2}$ (dark storage time $\mathrm{e}^{3} \times$ enhancement $^{4} \times$ hour of retail display) of repackaged steaks displayed for $144 \mathrm{~h}$

\begin{tabular}{|c|c|c|c|c|c|c|c|c|c|}
\hline \multirow[b]{2}{*}{ Parameter } & \multirow[b]{2}{*}{ Dark storage time } & \multirow[b]{2}{*}{ Enhancement } & \multicolumn{7}{|c|}{ Retail display hour } \\
\hline & & & 0 & 12 & 24 & 72 & 84 & 132 & 144 \\
\hline \multirow[t]{6}{*}{ Muscle color } & \multirow{3}{*}{$3 \mathrm{~d}$} & USDA Choice & $2.0^{\mathrm{abv}}$ & $1.5^{\mathrm{av}}$ & $1.8^{\mathrm{av}}$ & $2.2^{\mathrm{abcv}}$ & $2.6^{\mathrm{bcv}}$ & $2.9^{\text {cdv }}$ & $3.6^{\mathrm{dv}}$ \\
\hline & & $\mathrm{DCN}$ & $6.3^{\mathrm{ax}}$ & $6.3^{\mathrm{ayz}}$ & $6.3^{\operatorname{axy}}$ & $6.3^{\mathrm{awx}}$ & $6.5^{\mathrm{ax}}$ & $6.2^{\mathrm{axyz}}$ & $6.5^{\text {ay }}$ \\
\hline & & DCE & $4.5^{\mathrm{aw}}$ & $5.4^{\mathrm{bx}}$ & $6.0^{\text {bcxy }}$ & $6.1^{\mathrm{bcwx}}$ & $6.1^{\mathrm{bcwx}}$ & $6.2^{\text {bcxyz }}$ & $6.4^{\text {cxy }}$ \\
\hline & \multirow{3}{*}{$6 \mathrm{~d}$} & USDA Choice & $2.2^{\mathrm{abv}}$ & $2.0^{\mathrm{avw}}$ & $1.9^{\mathrm{av}}$ & $2.6^{\mathrm{abv}}$ & $3.0^{\mathrm{bcv}}$ & $3.6^{\mathrm{cvw}}$ & $3.6^{\mathrm{cv}}$ \\
\hline & & $\mathrm{DCN}$ & $6.8^{\mathrm{ax}}$ & $6.5^{\mathrm{az}}$ & $6.5^{\text {axy }}$ & $6.5^{\mathrm{awx}}$ & $6.6^{\mathrm{ax}}$ & $6.7^{\text {ay }}$ & $6.7^{\text {ay }}$ \\
\hline & & DCE & $5.2^{\mathrm{aw}}$ & $5.6^{\mathrm{axy}}$ & $5.9^{\mathrm{ax}}$ & $5.9^{\text {awx }}$ & $5.5^{\mathrm{aw}}$ & $5.9^{\text {axy }}$ & $5.7^{\mathrm{ax}}$ \\
\hline \multirow[t]{3}{*}{$\mathrm{SEM}=0.20$} & \multirow{3}{*}{$9 \mathrm{~d}$} & USDA Choice & $2.7^{\mathrm{av}}$ & $2.7^{\text {aw }}$ & $3.1^{\text {aw }}$ & $2.7^{\mathrm{av}}$ & $3.1^{\mathrm{av}}$ & $4.2^{\mathrm{bw}}$ & $4.7^{\text {bxy }}$ \\
\hline & & $\mathrm{DCN}$ & $6.8^{\mathrm{ax}}$ & $6.7^{\mathrm{az}}$ & $6.8^{\text {ay }}$ & $6.7^{\mathrm{ax}}$ & $6.8^{\mathrm{ax}}$ & $6.8^{\mathrm{az}}$ & $6.9^{\text {ay }}$ \\
\hline & & DCE & $4.6^{\mathrm{aw}}$ & $5.6^{\mathrm{bxy}}$ & $5.9^{\mathrm{bcx}}$ & $5.7^{\mathrm{bcw}}$ & $5.6^{\mathrm{bw}}$ & $5.5^{\mathrm{bx}}$ & $6.5^{\mathrm{cw}}$ \\
\hline \multirow[t]{6}{*}{ Surface discoloration } & \multirow{3}{*}{$3 \mathrm{~d}$} & USDA Choice & $1.3^{\mathrm{av}}$ & $1.2^{\mathrm{av}}$ & $1.1^{\mathrm{av}}$ & $1.3^{\mathrm{av}}$ & $1.4^{\mathrm{av}}$ & $1.8^{\mathrm{avw}}$ & $2.0^{\mathrm{av}}$ \\
\hline & & $\mathrm{DCN}$ & $1.0^{\mathrm{av}}$ & $1.0^{\mathrm{av}}$ & $1.0^{\mathrm{av}}$ & $1.1^{\mathrm{av}}$ & $1.1^{\mathrm{av}}$ & $1.2^{\mathrm{av}}$ & $1.5^{\mathrm{av}}$ \\
\hline & & DCE & $1.5^{\mathrm{av}}$ & $2.9^{\mathrm{bwx}}$ & $3.0^{\mathrm{bw}}$ & $3.4^{\mathrm{bw}}$ & $3.2^{\mathrm{bw}}$ & $3.3^{\mathrm{bxy}}$ & $3.4^{\mathrm{bwx}}$ \\
\hline & \multirow{3}{*}{$6 \mathrm{~d}$} & USDA Choice & $1.2^{\mathrm{av}}$ & $1.2^{\mathrm{av}}$ & $1.2^{\mathrm{av}}$ & $1.4^{\mathrm{av}}$ & $1.5^{\mathrm{av}}$ & $2.1^{\mathrm{avw}}$ & $2.1^{\mathrm{av}}$ \\
\hline & & $\mathrm{DCN}$ & $1.0^{\mathrm{av}}$ & $1.0^{\mathrm{av}}$ & $1.0^{\mathrm{av}}$ & $1.1^{\mathrm{abv}}$ & $1.2^{\mathrm{abv}}$ & $2.4^{\mathrm{cwx}}$ & $2.2^{\mathrm{bcvw}}$ \\
\hline & & DCE & $1.6^{\mathrm{av}}$ & $3.3^{\mathrm{bx}}$ & $3.7^{\mathrm{bw}}$ & $3.6^{\mathrm{bw}}$ & $3.6^{\mathrm{bw}}$ & $4.3^{\text {byz }}$ & $3.7^{\mathrm{bx}}$ \\
\hline \multirow[t]{3}{*}{$\mathrm{SEM}=0.29$} & \multirow{3}{*}{$9 \mathrm{~d}$} & USDA Choice & $1.8^{\mathrm{av}}$ & $1.81^{\mathrm{avw}}$ & $1.8^{\mathrm{av}}$ & $1.4^{\mathrm{av}}$ & $1.6^{\mathrm{av}}$ & $4.1^{\text {byz }}$ & $4.4^{\mathrm{bx}}$ \\
\hline & & $\mathrm{DCN}$ & $1.0^{\mathrm{av}}$ & $1.0^{\mathrm{av}}$ & $1.1^{\mathrm{av}}$ & $1.3^{\mathrm{abv}}$ & $1.5^{\mathrm{abv}}$ & $2.1^{\mathrm{abvw}}$ & $2.3^{\mathrm{bvw}}$ \\
\hline & & DCE & $1.4^{\mathrm{av}}$ & $2.9^{b w x}$ & $3.2^{\mathrm{bw}}$ & $3.2^{\mathrm{bw}}$ & $3.2^{\mathrm{bcw}}$ & $4.5^{\mathrm{dz}}$ & $4.3^{\mathrm{cdx}}$ \\
\hline
\end{tabular}

\footnotetext{
${ }^{1} 1=$ extremely bright cherry-red $2=$ bright cherry-red $3=$ moderately bright cherry-red $4=$ slight bright cherry-red $5=$ slightly dark cherry-red $6=$ moderately dark red $7=$ dark red.

${ }^{2} 1=$ no discoloration $2=$ minimal discoloration $3=$ slight discoloration $4=$ small discoloration $5=$ modest discoloration $6=$ moderate discoloration $7=$ extensive discoloration.

${ }^{3}$ Total time the steaks spent in dark storage prior to retail display.

${ }^{4}$ Treatments include normal-pH USDA Low Choice strip loin nonenhanced dark-cutting steaks in vacuum packaging (DCN) and dark-cutting steaks enhanced with $0.5 \%$ glucono delta-lactone and $0.1 \%$ rosemary solution and in nitrite-embedded packaging (DCE).

USDA Choice $n=6$; DCN/DCE $n=8$; SEM $=$ standard error of mean.

${ }^{a-d}$ Least-squares means within a row with different letters are significantly different $(P<0.05)$.

${ }^{\mathrm{v}-\mathrm{z}}$ Least-squares means within a column with different letters are significantly different $(P<0.05)$.
}

nonenhanced dark-cutting VP steaks by $24 \mathrm{~h}$ of display for steaks stored $3 \mathrm{~d}$ and $6 \mathrm{~d}$ in dark storage.

Nonenhanced dark-cutting VP steaks stored for $3 \mathrm{~d}$ in dark storage had no significant change in surface discoloration during retail display. USDA Choice steaks had no change $(P>0.05)$ in surface discoloration during retail display for 3-d and 6-d dark storage times, but steaks stored for $9 \mathrm{~d}$ in dark storage significantly increased in discoloration during the display period. Enhanced dark-cutting NP steaks increased $(P<0.05)$ in surface discoloration after $12 \mathrm{~h}$ of repackaging for all dark storage times, and the level of discoloration of repackaged enhanced dark-cutting NP steaks was more $(P<0.05)$ than USDA Choice and repackaged nonenhanced dark-cutting VP steaks. The surface discoloration of repackaged enhanced dark-cutting NP steaks was greater than USDA Choice and repackaged nonenhanced dark-cutting VP steaks at the end of the display period for steaks stored $3 \mathrm{~d}$ and $6 \mathrm{~d}$ in dark storage $(P<0.05)$. With an increased dark storage time to

$9 \mathrm{~d}$, the discoloration increased significantly with increased display hour for repackaged enhanced darkcutting NP steaks. By the end of the retail display, the repackaged enhanced dark-cutting NP steaks had a similar $(P>0.05)$ level of discoloration to USDA Choice steaks.

\section{Aerobic plate count}

There was a significant dark storage time $\times$ enhancement effect for aerobic plate count (Table 6). The USDA Choice steaks had a lower $(P<0.05)$ aerobic plate count than the enhanced dark-cutting steaks and nonenhanced dark-cutting steaks for all dark storage periods. Nonenhanced dark-cutting VP steaks had greater $(P<0.05)$ aerobic plate counts than enhanced dark-cutting NP steaks during $6 \mathrm{~d}$ of dark storage. However, no differen- 
Table 6. Effects of dark storage time ${ }^{1}$ and enhancement $^{2}$ on microbial growth of repackaged steaks displayed for $144 \mathrm{~h}$

\begin{tabular}{lll}
\hline \hline Dark storage time & Enhancement & $\log \left(\mathrm{CFU} / \mathrm{cm}^{2}\right)$ \\
\hline $3 \mathrm{~d}$ & USDA Choice & $4.99^{\mathrm{a}}$ \\
& DCN & $6.95^{\mathrm{bc}}$ \\
& DCE & $6.20^{\mathrm{b}}$ \\
$6 \mathrm{~d}$ & USDA Choice & $4.89^{\mathrm{a}}$ \\
& DCN & $7.59^{\mathrm{c}}$ \\
& DCE & $6.41^{\mathrm{b}}$ \\
$9 \mathrm{~d}$ & USDA Choice & $4.99^{\mathrm{a}}$ \\
& DCN & $6.39^{\mathrm{b}}$ \\
& DCE & $6.23^{\mathrm{b}}$ \\
SEM $=0.21$ & & \\
\hline
\end{tabular}

\footnotetext{
${ }^{1}$ Total time the steaks spent in dark storage prior to retail display.

${ }^{2}$ Treatments include normal-pH USDA Low Choice strip loin nonenhanced dark-cutting steals in vacuum packaging (DCN) and dark-cutting strip loin enhanced with $0.5 \%$ glucono delta-lactone and $0.1 \%$ rosemary solution and in nitrite-embedded packaging (DCE).

USDA Choice, $n=6$; nonenhanced and enhanced dark-cutting, $n=8$; $\mathrm{SEM}=$ standard error of mean.

${ }^{\mathrm{a}-\mathrm{c}}$ Least-squares means with different letters are significantly different $(P<0.05)$.
}

ces in aerobic plate count were noted between nonenhanced dark-cutting VP steaks and enhanced dark-cutting NP steaks with $9 \mathrm{~d}$ of dark storage.

\section{Discussion}

Anaerobically packaged NP film improves redness of normal-pH and high-pH beef. Nitrite from packaging film migrates to meat and will react with myoglobin to form bright-red nitric oxide myoglobin. The mechanistic basis for the interconversion of myoglobin forms within NP is not clear. Previous research noted the formation of nitric oxide myoglobin occurs through the reduction of nitric oxide metmyoglobin in vitro (Fox Jr. and Ackerman, 1968). When meat is packaged in nitrite film, myoglobin is oxidized to form nitric oxide metmyoglobin. Anaerobic packaging favors oxygen consumption and also metmyoglobin reducing activity. Therefore, reducing capacity of meat plays an important step in how quickly nitric oxide myoglobin can form on meat surface (Denzer et al., 2020). The reducing capacity of meat is critical in converting nitric metmyoglobin to form nitric oxide myoglobin. Dark-cutting beef has more metmyoglobin reducing activity compared with normal-pH beef (English et al., 2016; McKeith et al., 2016; Ramanathan et al., 2020b). Therefore, greater metmyoglobin reducing activity allows faster reduction and nitric oxide myoglobin formation. In support, Ramanathan et al. (2018) demonstrated the formation of metmyoglobin on day 0 in NP. Additionally, an increase in nitric oxide myoglobin formation was shown in dark-cutting steaks in NP film packaged during 24-h retail display, and the nitric oxide myoglobin formation significantly increased in the presence of rosemary from day 1 to day 3 of retail display (Ramanathan et al., 2018). This parallels with the nitric oxide myoglobin increase seen in this study. However, limited knowledge is currently available on the effects of repackaging anaerobically formed brightred nitric oxide myoglobin in dark-cutting steaks. The current study demonstrated that exposure to aerobic condition decreased bright-red color of dark-cutting steaks. Claus and $\mathrm{Du}(2013)$ reported that $L^{*}$ and $a^{*}$ values significantly decreased for repackaged normal$\mathrm{pH}$ steaks in $6 \mathrm{~h}$ of retail display. A similar decline in $a^{*}$ values was seen in this study at $12 \mathrm{~h}$.

At a $\mathrm{pH}$ of 6.7 in vitro, nitric oxide myoglobin is oxidized rapidly in light and oxygen conditions to form metmyoglobin (Walsh and Rose, 1956), indicating the implications of retail display conditions on the oxidation of nitric oxide myoglobin. Additionally, nitric oxide myoglobin oxidation is greater at elevated $\mathrm{pHs}$ (Walsh and Rose, 1956; Munk et al., 2010), demonstrating an increased susceptibility for oxidation in dark-cutting beef. Siegel (2011) reported that the nitrite migrated from packaging material was less than $2 \mathrm{ppm}$ using NP film. In support, Claus and Du (2013) demonstrated that the residual nitrite in the NP film packaged beef was $1.44 \mathrm{ppm}$ in the longissimus of normal-pH steaks. Claus and Du (2013) noted an increase in metmyoglobin with an increased display time after repackaging steaks in PVC. In the present study, there was an increase in surface discoloration and a decrease in redness within the first $12 \mathrm{~h}$. After $12 \mathrm{~h}$, there were limited changes in redness, likely owing to the antioxidant effect of rosemary. In support, a previous study noted that dark-cutting steaks dipped in rosemary and packaged in NP had greater redness than steaks packaged in NP film (Ramanathan et al., 2018).

Enhancement of dark-cutting beef with weak organic acids improved lightness of dark-cutting beef (Sawyer et al., 2009; Apple et al., 2011; Stackhouse et al., 2016; Tapp et al., 2017). Furthermore, the addition of acid generating glucono delta-lactone was also reported to increase $L^{*}$ values of dark-cutting beef (Dolezal et al., 2013). In support, Hughes et al. (2017) noted that increased water on the surface of steaks can promote light scattering and lightness ( $L^{*}$ values).

Dark-cutting beef has more microbial growth due to greater-than-normal pH (Gill and Newton, 1979). 
Acidification by glucono delta-lactone decreased microbial growth for various meat products (Farkas and Andrássy, 1993; Maijala et al., 1993). NP results in a 1-log reduction of microbial growth due to anaerobic conditions (Yang et al., 2016; Narváez-Bravo et al., 2017; Ramanathan et al., 2018). In the current research, the enhancement and NP did not provide a significant decline in microbial growth compared with nonenhanced dark-cutting steaks, possibly owing to contamination through the injection process.

\section{Conclusions}

The use of glucono delta-lactone in combination with NP film improved the color of dark-cutting steaks. However, repackaging enhanced NP steaks in PVC resulted in a decline in red appearance and an increase in discoloration in comparison with USDA Choice steaks. In conclusion, anaerobic NP improved the redness of dark-cutting steaks; however, repackaging NP steaks in aerobic conditions increased discoloration.

\section{Acknowledgement}

The authors would like to thank Amcor for providing FreshCase ${ }^{\circledR}$ packaging to conduct the research.

\section{Literature Cited}

AMSA. 2012. Meat color measurement guidelines. Am. Meat Sci. Assoc. Champaign, IL.

Apple, J. K., J. T. Sawyer, J. F. Meullenet, J. W. S. Yancey, and M. D. Wharton. 2011. Lactic acid enhancement can improve the fresh and cooked color of dark-cutting beef. J. Anim. Sci. 89:4207. https://doi.org/10.2527/jas.2011-4147.

Carpenter, C. E., D. P. Cornforth, and D. Whittier. 2001. Consumer preferences for beef color and packaging did not affect eating satisfaction. Meat Sci. 57:359-363. https://doi.org/10.1016/ S0309-1740(00)00111-X.

Claus, J. R., and C. Du. 2013. Nitrite-embedded packaging film effects on fresh and frozen beef color development and stability as influenced by meat age and muscle type. Meat Sci. 95:526-535. https://doi.org/10.1016/j.meatsci.2013.05.029.

Denzer, M. L., C. Mowery, H. A. Comstock, N. B. Maheswarappa, G. Mafi, D. L. VanOverebeke, and R. Ramanathan. 2020. Characterization of the cofactors involved in non-enzymatic metmyoglobin/methemoglobin reduction in vitro. Meat Muscle Biol. 4(1). (In press).

Dolezal, H. G. J., D. Mckenna, D. L. Schaefer, and R. Steiner. 2013. Treating meat from dark-cuting carcasses using an acidification process. In: US Patent Office, editor, Cargill, Incorporated, United States.
English, A. R., B. N. Harsh, D. L. VanOverbeke, G. G. Mafi, K. M. Wills, and R. Ramanathan. 2016. Effects of aging on the fundamental color chemistry of dark-cutting beef. J. Anim. Sci. 94:4040-4048. https://doi.org/10.2527/jas.2016-0561.

Farkas, J., and É. Andrássy. 1993. Interaction of ionising radiation and acidulants on the growth of the microflora of a vacuumpackaged chilled meat product. Int. J. Food Microbiol. 19:145-152. https://doi.org/10.1016/0168-1605(93)90180-O.

Fox Jr., J. B., and S. A. Ackerman. 1968. Formation of nitric oxide myoglobin: Mechanisms of the reaction with various reductants. J. Food Sci. 33:364-370. https://doi.org/10.1111/j. 1365-2621.1968.tb03631.x.

Gill, C. O., and K. G. Newton. 1979. Spoilage of vacuum-packaged dark, firm, dry meat at chill temperatures. Appl. Environ. Microb. 37:362-364.

Gill, C. O., and N. Penney. 1986. Packaging conditions for extended storage of chilled dark, firm, dry beef. Meat Sci. 18:41-53. https://doi.org/10.1016/0309-1740(86)90065-3.

Grebitus, C., H. H. Jensen, J. Roosen, and J. G. Sebranek. 2013. Fresh meat packaging: Consumer acceptance of modified atmosphere packaging including carbon monoxide. J. Food Protect. 76:99107. https://doi.org/10.4315/0362-028x.Jfp-12-045.

Hughes, J., F. Clarke, P. Purslow, and R. Warner. 2017. High pH in beef longissimus thoracis reduces muscle fibre transverse shrinkage and light scattering which contributes to the dark colour. Food Res. Int. 101:228-238. https://doi.org/10. 1016/j.foodres.2017.09.003

Kinnear, P., and A. Sahraie. 2002. New Farnsworth-Munsell 100 hue test norms of normal observers for each year of age 522 and for age decades 30-70. Brit. J. Ophthalmol. 86:1408-1411. https://doi.org/10.1136/bmj.2.3799.796-a.

Lawrie, R. A. 1958. Physiological stress in relation to dark-cutting beef. J. Sci. Food Agr. 9:721-727. https://doi.org/10.1002/ jsfa.2740091106.

Maijala, R. L., S. H. Eerola, M. A. Aho, and J. A. Hirn. 1993. The effect of GDL-induced $\mathrm{pH}$ decrease on the formation of biogenic amines in meat. J. Food Protect. 56:125-129. https:// doi.org/10.4315/0362-028x-56.2.125.

McKeith, R. O., D. A. King, A. L. Grayson, S. D. Shackelford, K. B. Gehring, J. W. Savell, and T. L. Wheeler. 2016. Mitochondrial abundance and efficiency contribute to lean color of dark cutting beef. Meat Sci. 116:165-173. https:// doi.org/10.1016/j.meatsci.2016.01.016.

Mitacek, R. M., A. R. English, G. G. Mafi, D. L. VanOverbeke, and R. Ramanathan. 2018. Modified atmosphere packaging improves surface color of dark-cutting beef. Meat Muscle Biol. 2:57-63. https://doi.org/10.22175/mmb2017.04.0023.

Mitacek, R. M., Y. Ke, J. E. Prenni, R. Jadeja, D. L. VanOverbeke, G. G. Mafi, and R. Ramanathan. 2019. Mitochondrial degeneration, depletion of $\mathrm{NADH}$, and oxidative stress decrease color stability of wet-aged beef longissimus steaks. J. Food Sci. 84:38-50. https://doi.org/10.1111/1750-3841.14396.

Munk, M. B., K. Huvaere, J. Van Bocxlaer, and L. H. Skibsted. 2010. Mechanism of light-induced oxidation of nitrosylmyoglobin. Food Chem. 121:472-479. https://doi.org/10.1016/j. foodchem.2009.12.067.

Narváez-Bravo, C., A. Rodas-González, C. Ding, O. LópezCampos, J. Galbraith, I. L. Larsen, J. Ye, D. Siegel, and J. 
L. Aalhus. 2017. Effects of novel nitrite packaging film on the bacterial growth of bison strip-loin steaks. J. Food Process. Pres. 41:13311. https://doi.org/10.1111/jfpp.13311.

Ramanathan, R., D. L. VanOverbeke, G. G. Mafi, M. M. Pfeiffer, R. M. Mitacek, R. Jadeja, and S. D. Billups. 2018. Novel nitrite-embedded packaging improves surface redness of dark-cutting longissimus steaks. Translational Animal Science. 2:135-143. https://doi.org/10.1093/tas/ txy006.

Ramanathan, R., M. C. Hunt, R. Mancini, M. N. Nair, M. L. Denzer, S. P. Suman, and G. G. Mafi. 2020a. Recent updates in meat color research: Integrating traditional and highthroughput approaches. Meat Muscle Biol. 4:1-24. https:// doi.org/10.22175/mmb.9598.

Ramanathan, R., F. Kiyimba, J. Gonzalez, G. Mafi, and U. DeSilva. 2020b. Impact of up- and downregulation of metabolites and mitochondrial content on $\mathrm{pH}$ and color of the longissimus muscle from normal-pH and dark-cutting beef. J. Agr. Food Chem. 68:7194-7203. https://doi.org/10.1021/acs.jafc. 0c01884.

Ramanathan, R., M. C. Hunt, A. R. English, G. G. Mafi, and D. L. VanOverbeke. 2019. Effects of aging, modified atmospheric packaging, and display time on metmyoglobin reducing activity and oxygen consumption of high-pH beef. Meat Muscle Biol. 3:276. https://doi.org/10.22175/mmb2019.05.0017.

Roberts, J. C., A. Rodas-González, J. Galbraith, M. E. R. Dugan, I. L. Larsen, J. L. Aalhus, and Ó. López-Campos. 2017. Nitrite embedded vacuum packaging improves retail color and oxidative stability of bison steaks and patties. Meat Muscle Biol. 1:169-180. https://doi.org/10.22175/mmb2017.03.0015.

Sawyer, J. T., J. K. Apple, Z. B. Johnson, R. T. Baublits, and J. W. S. Yancey. 2009. Fresh and cooked color of dark-cutting beef can be altered by post-rigor enhancement with lactic acid. Meat Sci. 83:263-270. https://doi.org/10.1016/j.meatsci. 2009.05.008.
Scanga, J. A., K. E. Belk, J. D. Tatum, T. Grandin, and G. C. Smith. 1998. Factors contributing to the incidence of dark cutting beef. J. Anim. Sci. 76:2040-2047.

Siegel, D. 2011. An update on packaging fresh meat with nitrite containing film. Presented at: 64th Reciprocal Meat Conference, Kansas State University. June 22.

Stackhouse, R., J. Apple, J. Yancey, C. Keys, T. Johnson, and L. Mehall. 2016. Postrigor citric acid enhancement can alter cooked color but not fresh color of dark-cutting beef. J. Anim. Sci. 94:1738-1754. https://doi.org/10.2527/jas.2015-0181.

Tapp, W. N., C. T. Christjohn, D. A. Griffing, and C. L. Bratcher. 2017. Evaluation of meat quality on high $\mathrm{pH}$ strip loins injected with buffered acetic acid. Meat Muscle Biol. 1:218-226. https://doi.org/10.22175/mmb2017.04.0020.

Walsh, K. A., and D. Rose. 1956. Meat pigments, factors affecting the oxidation of nitric oxide myoglobin. J. Agr. Food Chem. 4:352-355. https://doi.org/10.1021/jf60062a008.

Wills, K. M., R. M. Mitacek, G. G. Mafi, D. L. VanOverbeke, D. Jaroni, R. Jadeja, and R. Ramanathan. 2017. Improving the lean muscle color of dark-cutting beef by aging, antioxidant-enhancement, and modified atmospheric packaging. J. Anim. Sci. 95:5378-5387. https://doi.org/10.2527/jas2017. 1967.

Yang, X., D. R. Woerner, J. D. Hasty, K. R. McCullough, I. Geornaras, J. N. Sofos, and K. E. Belk. 2016. An evaluation of the effectiveness of FreshCase technology to extend the storage life of whole muscle beef and ground beef. J. Anim. Sci. 94:4911-4920. https://doi.org/10.2527/jas. 2016-0508.

Zhang, Y., L. Qin, Y. Mao, D. L. Hopkins, G. Han, L. Zhu, and X. Luo. 2018. Carbon monoxide packaging shows the same color improvement for dark cutting beef as high oxygen packaging. Meat Sci. 137:153-159. https://doi.org/10.1016/j.meatsci. 2017.11.016. 